\title{
Monitoring and Control System by Using Wireless Sensor Network for Ground water Well's Field in South of Iraq
}

\author{
Alaa. Qassim Rahima, Hiba. A. Tarish, Narjis. Sapih \\ Civil Engineering Department, University of Technology, Baghdad, Iraq
}

\begin{abstract}
Recently, the using of wireless sensor network as the most important technique necessary according different application, such as water resources conditions for living in safe. This is due to the shortage in groundwater, river resources and rain level. This project design a structure of complete wireless sensor network structure to monitor the different water levels and verity water quality according to water well-field and the consumed electrical power of the installed pump. The utilized sensors use the energy saving techniques and allocate the controller sensor to work as a PAN coordinator. The designed structure has been implemented and tested using SQL,GUI under the environment of visual studio C\#. The obtained results from the simulator appear the efficient of the system in monitoring the wells factors.
\end{abstract}

Keywords : Wireless Sensor Network, Wells Field, SQL, Visual Studio C\#, GUI.

\section{INTRODUCTION}

Water is one of nature's most valuable resource and fresh water supplies are pushed to the brink of nonrenewability by the growing demands on them, [1]. Groundwater resource management is an important issue, especially with regard to agricultural potential [2]. Therefore, it is essential to presents a monitoring system for groundwater wells using wireless sensors and preparation of the control system that has updated information. This is to monitor the critical parameter that affects the groundwater, such as wells water level, EC, consumed power, providing a mechanism to build pumps operation system. For minimizing the consumed operation power and supplying the required water demand.

In [3], groundwater monitoring system has been proposed using wireless pressure sensor network. This is to offer an access to the ground water information by researcher. In [4] authors proposed an irrigation management system based on ZigBee technology. The study showed the suitability of ZigBee for precision agriculture due to its low power consumption, cost and data rate of operation which meet Precision Agriculture (PA) requirements. In [5], real-time monitoring system of groundwater in Korea has been proposed as a mini- review. This is to introduce a continues monitoring of the current status of the ground water networks that can be works in Korea in which some suggestions were presented to enhance the situation of current control and decision making in Korea ground water.

In this paper, a model of wireless sensor network structure is proposed to monitor the essential parameters in the water field of a considered site in Karbala, Iraq. In this structure, a PAN coordinator nodes have been used to control the data flow between the sensor nodes to reduce the periodic time in this network. 


\section{METHODS AND MATERIAL}

\section{The Description of the proposed system}

In this section, the proposed system is explained in sub-section to ease the reading influence:

\subsection{Structure of Wireless Sensor Network (WSN)}

WSN uses the IEEE 802 .15.4 network standard for PAN's nodes. In addition, the physical layer adopts to operating in $2.4 \mathrm{GHZ}$ rate of data, it's the limitation band low data rates are suitable for environmental monitoring application like agriculture [6]. Based on the network structure, the WSN can be classify as flat (data centric), hierarchical (cluster-based) and location based (geographical) protocols. These protocols can minimize the total of message passing in efficient way [7] and [8]. The star topology is the best choice for the irrigation applications as it is suitable to small networks in low density of nodes deployment [9]

The model of proposed system is shown in Figure (1). It explains the distribution of wells amongst the groundwater field. In addition, the pipes as well as the pumps on these well. The data is transmitted to the control station in wireless techniques throughout the sink (PAN) nodes. The sensor nodes are classified into the following: the main controller node in this network is PAN coordinator, the (FFDs) node supports the data movement and routing by connecting verity type of networks constriction then forwarding the received messages from the end node until reaching the PAN coordinator. Every node receives a massages coming from all wells in the farm for more processing. In order to manage the traffic model, the network can be classified into: proactive (time-driven model), reactive (exception-driven model), and hybrid network .The sensor nodes in the proactive network [10] and [11]. The hybrid network is efficient in agricultural application due to limited time and fast response to the environmental changes provided from the value of the parameters of sensor [12]. Table I shows the important parameters of the utilized sensor network [6].

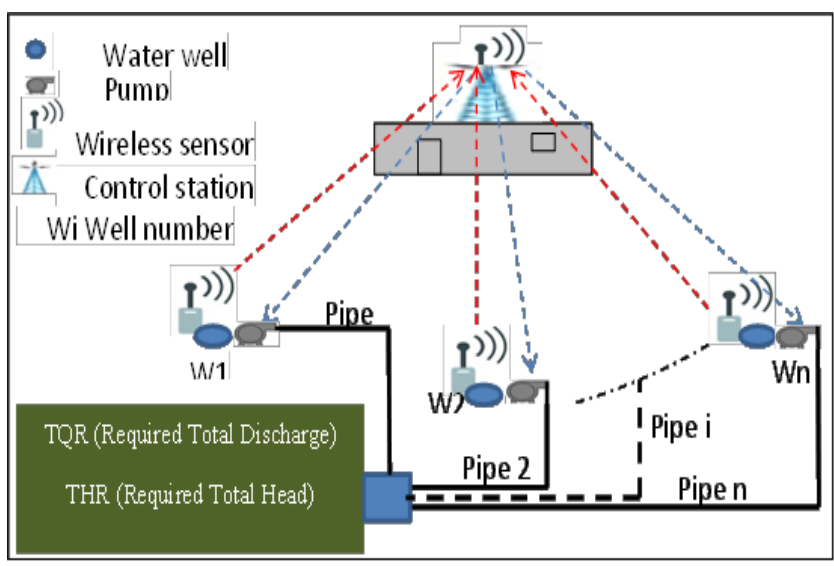

Figure 1. Structure of WSN based model for wellfield operation

\section{RESULTS AND DISCUSSION}

\subsection{Groundwater Well- Field}

According to agriculture applications, there is a limited distance between the considered nodes [12]. Therefore, the distance between the nodes in the designed structure is reduced to minimum in which the system works efficiently. In proposed system, three farms (A,B, and C) with complete area of 1000 Dunam.The field includes 24 sensor nodes distributed over 24 wells. These wells are distributed into (4) wells in farm A. 16 wells in farm B and (4) wells in C.

\subsection{Simulated Results}

As highlighted previously, the proposed system has been designed in visual studio $\mathrm{C \#}$ environment in addition to build the database for storing the considered information using SQL server software. The designed GUIs of the proposed system are introduced to simulate the real life of the wells working and to ease the using of it by unskilled users. Figure (2) shows the main interface GUI that provides the user with easy method of implementing the guided procedure. 
A database contains the well-field characteristics and the farm irrigation requirements are conducted and linked with the control system as an input files. The well-field characteristics file includes number of wells and well names, well discharge (Q), Pipe length (L), Pipe diameter (D), pump discharge $(\mathrm{Qw})$ and pump efficiency constants (A, B, and C ). While the farm irrigation requirements includes the daily required total discharge (TQR) and the total required head (THR) at the farm, such as these listed in Appendix A. in this study, to simplify the application and evaluation of proposed control system the TQR inputted manually as single value for one day. Whereas, in real application of the system it can be inputted as a database file.

The Drawdown in well (HS), EC and actual consumed power (Pact) sensors reading data are directly transmitted and inputted to the system as mentioned in section 4-2. Also, the threshold values of the alarm system (EC threshold, Day threshold are manually inputted. This enables the decision maker to change these values for inclusion or exclusion the alarmed wells from the turn-on or turn-off of criteria
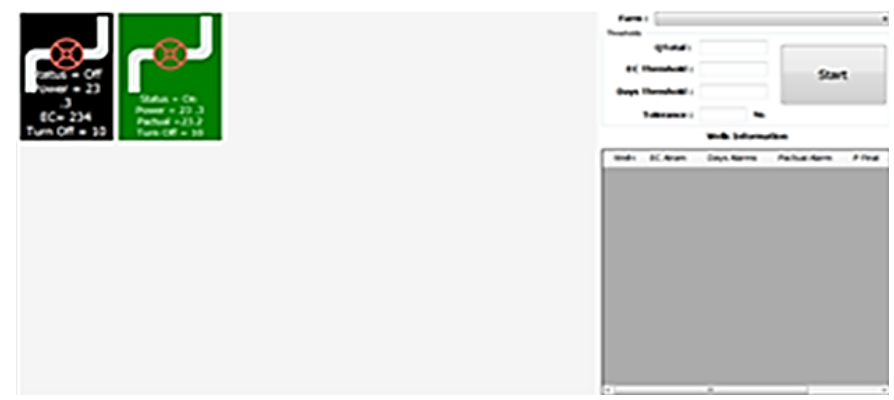

Figure 2. The the main GUI fram

From this figure, the top right side includes the fields of required information that contains(Farm selection, Q Total: total required discharge of the selected farm, EC Threshold: allowable electrical conductivity of water in the considered wells, Days Threshold: the allowable number of well turnoff days, Tolerance: difference between the actual power according to sensor readings and the computed power value.

Evaluation of Farm A: Farm A includes four wells each one includes three sensors to measure drawdown in well (HS), EC and actual consumed power (Pact). Table (4.3) shows the received sensors' readings at the control center that have been stored in the built database. This table represents the stored sensors' readings and related information of the adopted wells of Farm A.

Where Q: well discharge, L: pipe length, D: pipe dimeter, (A, B and C) are constant values used for evaluating the pump efficiency, HS: sensor reading of drawdown in well, EC: sensor reading of electrical conductivity, Pact: sensor reading of consumed power of pump It is important to note that the Pact is considered as zeros for turning on the power alarm of wells in testing case.

It is important to note that the EP: power efficiency, Pfinal: consumed power, TH: total head loss and HL: head loss of each well

\section{FARM A: Scenario 1}

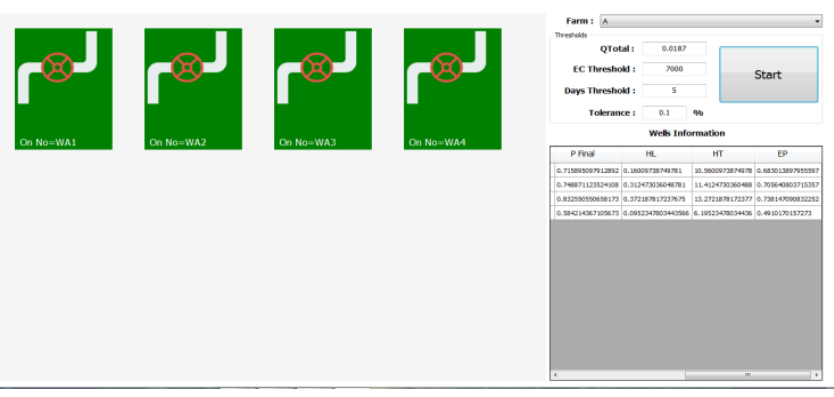

Figure 3. GUI of first scenario / Farm A. 
Table 1. well- information in Farm A

\begin{tabular}{|c|c|c|c|c|c|c|c|c|c|}
\hline \multirow{2}{*}{ WELL } & \multicolumn{5}{|c|}{ Well-field characteristics } & \multicolumn{3}{|c|}{ Sensor reading } \\
\cline { 2 - 10 } & QW & L & D & A & B & C & HS & EC & Pact \\
\hline W1 & 0.00472 & 311 & 1.5 & -0.3343 & 10 & -0.0199 & 10.4 & 6350 & 0 \\
\hline W2 & 0.00472 & 607 & 1.5 & -0.3343 & 10 & -0.0199 & 11.1 & 6230 & 0 \\
\hline W3 & 0.00472 & 723 & 1.5 & -0.3343 & 10 & -0.0199 & 12.9 & 6490 & 0 \\
\hline W4 & 0.00472 & 185 & 1.5 & -0.3343 & 10 & -0.0199 & 6.1 & 6280 & 0 \\
\hline
\end{tabular}

Table 2. obtained results of first scenario / Farm A

\begin{tabular}{|c|c|c|c|c|c|c|c|c|}
\hline $\begin{array}{c}\text { Well } \\
\text { Name }\end{array}$ & $\begin{array}{c}\text { EC } \\
\text { Alarm }\end{array}$ & Days Alarms & $\begin{array}{c}\text { Pact } \\
\text { Alarms }\end{array}$ & Pfinal & HL & HT & EP & $\begin{array}{c}\text { Operatio } \\
\mathbf{n}\end{array}$ \\
\hline WA1 & CLEAR & $\begin{array}{c}\text { This well } \\
\text { turn off for } \\
\text { long time }\end{array}$ & $\begin{array}{c}\text { Pactual } \\
\text { Alarm }\end{array}$ & 0.7158 & 0.1600 & 10.5600 & 0.6830 & On \\
\hline WA2 & CLEAR & $\begin{array}{c}\text { This well } \\
\text { turn off for } \\
\text { long time }\end{array}$ & $\begin{array}{c}\text { Pactual } \\
\text { Alarm }\end{array}$ & 0.7488 & 0.3124 & 11.4124 & 0.7056 & On \\
\hline WA3 & CLEAR & $\begin{array}{c}\text { This well } \\
\text { turn off for } \\
\text { long time }\end{array}$ & $\begin{array}{c}\text { Pactual } \\
\text { Alarm }\end{array}$ & 0.8325 & 0.3721 & 13.2721 & 0.7381 & On \\
\hline WA4 & CLEAR & $\begin{array}{c}\text { This well } \\
\text { turn off for } \\
\text { long time }\end{array}$ & $\begin{array}{c}\text { Pactual } \\
\text { Alarm }\end{array}$ & 0.5842 & 0.0952 & 6.1952 & 0.4910 & On \\
\hline
\end{tabular}

\section{FARM A : Scenario 2}

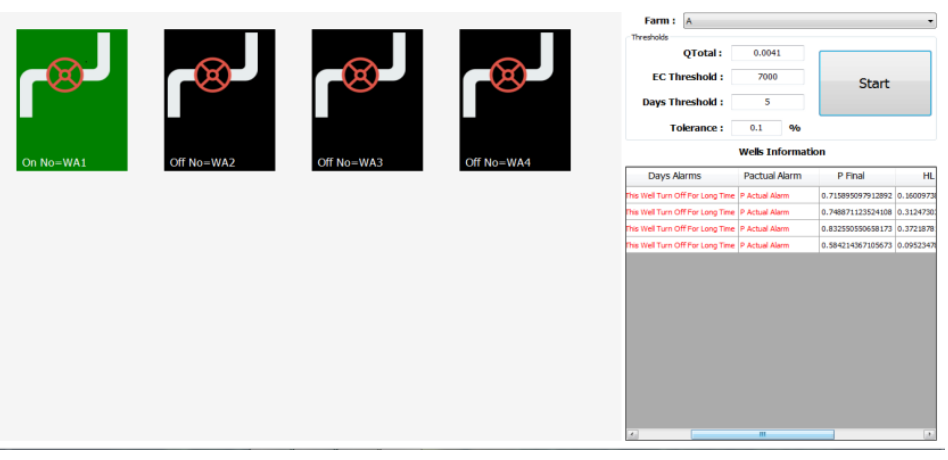

Figure 4. GUI of second scenario / Farm A.

Table 3. obtained results of second scenario / Farm A.

\begin{tabular}{|c|c|c|c|c|c|c|c|c|}
\hline $\begin{array}{c}\text { Well } \\
\text { Nam } \\
\text { e }\end{array}$ & $\begin{array}{c}\text { EC } \\
\text { Alarm }\end{array}$ & $\begin{array}{c}\text { Days } \\
\text { Alarms }\end{array}$ & $\begin{array}{c}\text { Pactual } \\
\text { Alarms }\end{array}$ & Pfinal & HL & HT & EP & $\begin{array}{c}\text { Operatio } \\
\mathbf{n}\end{array}$ \\
\hline WA1 & CLEAR & $\begin{array}{c}\text { This well } \\
\text { turn off }\end{array}$ & $\begin{array}{c}\text { P } \\
\text { Actual }\end{array}$ & 0.7158 & 0.1600 & 10.5600 & 0.6830 & Off \\
\hline
\end{tabular}




\begin{tabular}{|c|c|c|c|c|c|c|c|c|}
\hline & & $\begin{array}{c}\text { for long } \\
\text { time }\end{array}$ & Alarm & & & & & \\
\hline WA2 & CLEAR & $\begin{array}{c}\text { This well } \\
\text { turn off } \\
\text { for long } \\
\text { time }\end{array}$ & $\begin{array}{c}\text { P } \\
\text { Actual } \\
\text { Alarm }\end{array}$ & 0.7488 & 0.3124 & 11.4124 & 0.7056 & Off \\
\hline WA3 & CLEAR & $\begin{array}{c}\text { This well } \\
\text { turn off } \\
\text { for long } \\
\text { time }\end{array}$ & $\begin{array}{c}\text { P } \\
\text { Actual } \\
\text { Alarm }\end{array}$ & 0.8325 & 0.3721 & 13.2721 & 0.7381 & Off \\
\hline WA4 & CLEAR & $\begin{array}{c}\text { This well } \\
\text { turn off } \\
\text { for long } \\
\text { time }\end{array}$ & $\begin{array}{c}\text { Pctual } \\
\text { Alarm }\end{array}$ & 0.5842 & 0.0952 & 6.1952 & 0.4910 & On \\
\hline
\end{tabular}

FARM A: Scenario 3

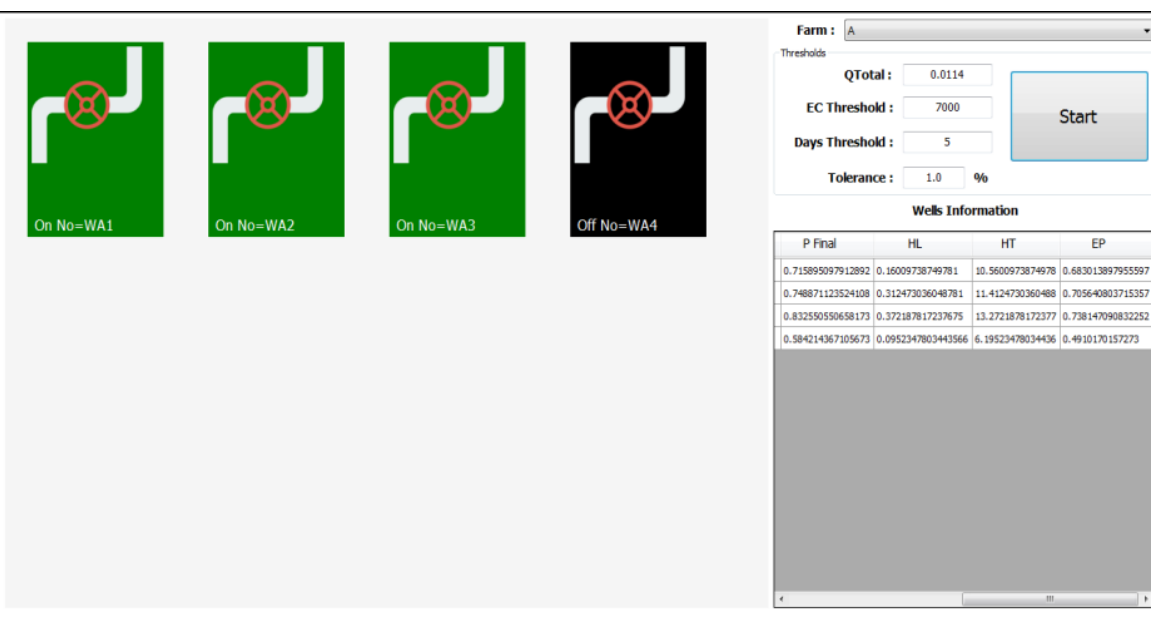

Figure 5. GUI of third scenario / Farm A

Table 4. obtained results of third scenario / Farm A.

\begin{tabular}{|c|c|c|c|c|c|c|c|c|}
\hline $\begin{array}{c}\text { Well } \\
\text { Name }\end{array}$ & $\begin{array}{c}\text { EC } \\
\text { Alarm }\end{array}$ & $\begin{array}{c}\text { Days } \\
\text { Alarms }\end{array}$ & $\begin{array}{c}\text { Pactual } \\
\text { Alarms }\end{array}$ & Pfinal & HL & HT & EP & Operation \\
\hline WA1 & CLEAR & $\begin{array}{c}\text { This } \\
\text { well } \\
\text { turn off } \\
\text { for long } \\
\text { time }\end{array}$ & $\begin{array}{c}\text { Pactual } \\
\text { Alarm }\end{array}$ & 0.7158 & 0.1600 & 10.5600 & 0.6830 & On \\
\hline WA2 & CLEAR & $\begin{array}{c}\text { This } \\
\text { well } \\
\text { turn off } \\
\text { for long } \\
\text { time }\end{array}$ & $\begin{array}{c}\text { Pactual } \\
\text { Alarm }\end{array}$ & 0.7488 & 0.3124 & 11.4124 & 0.7056 & On \\
\hline WA3 & CLEAR & $\begin{array}{c}\text { This } \\
\text { well } \\
\text { turn off } \\
\text { for long }\end{array}$ & $\begin{array}{c}\text { Pactual } \\
\text { Alarm }\end{array}$ & 0.8325 & 0.3721 & 13.2721 & 0.7381 & Off \\
\hline
\end{tabular}




\begin{tabular}{|l|l|c|c|c|c|c|c|c|}
\hline & & time & & & & & & \\
\hline WA4 & CLEAR & $\begin{array}{c}\text { This } \\
\text { well } \\
\text { turn off } \\
\text { for long } \\
\text { time }\end{array}$ & $\begin{array}{c}\text { Pactual } \\
\text { Alarm }\end{array}$ & 0.5842 & 0.0952 & 6.1952 & 0.4910 & On \\
\hline
\end{tabular}

\section{Evaluation of Farm B}

In Farm B, sixteen wells have been considered. The received sensors' readings and the related important information are saved in the built database as shown in Table (4.7). Moreover, the adopted parameters are the same as in Farm A. Three scenarios are chosen to test the system on Farm B.
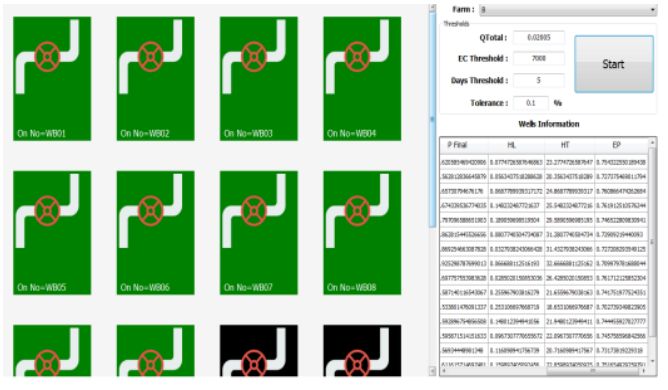
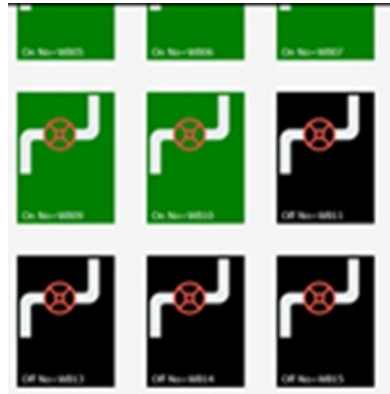
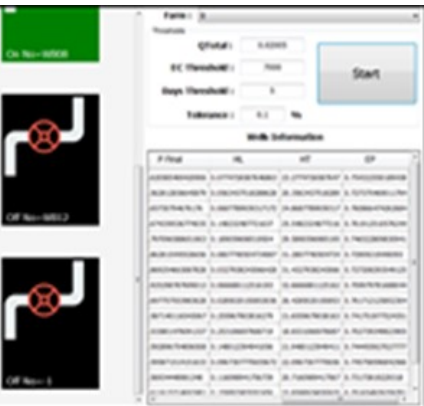

Figure 6. Resulting GUI of third scenario / Farm B.

Table 5. obtained results of third scenario / Farm B

\begin{tabular}{|c|c|c|c|c|c|c|c|c|}
\hline $\begin{array}{l}\text { Well } \\
\text { Name }\end{array}$ & EC Alarms & Days Alarms & $\begin{array}{l}\text { Pactual } \\
\text { Alarm }\end{array}$ & Pfinal & HL & HT & EP & Operation \\
\hline WB1 & CLEAR & $\begin{array}{l}\text { This well turn off } \\
\text { for long time }\end{array}$ & $\begin{array}{l}\text { Pactual } \\
\text { Alarm }\end{array}$ & 0.6205 & 0.0774 & 23.2774 & 0.7543 & On \\
\hline WB2 & CLEAR & $\begin{array}{l}\text { This well turn off } \\
\text { for long time }\end{array}$ & $\begin{array}{l}\text { Pactual } \\
\text { Alarm }\end{array}$ & 0.5628 & 0.0563 & 20.3563 & 0.7273 & On \\
\hline WB3 & CLEAR & $\begin{array}{l}\text { This well turn off } \\
\text { for long time }\end{array}$ & $\begin{array}{l}\text { Pactual } \\
\text { Alarm }\end{array}$ & 0.6573 & 0.0687 & 24.8687 & 0.7608 & On \\
\hline WB4 & CLEAR & $\begin{array}{l}\text { This well turn off } \\
\text { for long time }\end{array}$ & $\begin{array}{l}\text { Pactual } \\
\text { Alarm }\end{array}$ & 0.6743 & 0.1482 & 25.5482 & 0.7639 & Off \\
\hline WB5 & CLEAR & $\begin{array}{l}\text { This well turn off } \\
\text { for long time }\end{array}$ & $\begin{array}{l}\text { Pactual } \\
\text { Alarm }\end{array}$ & 0.7970 & 0.1890 & 29.5890 & 0.7465 & Off \\
\hline WB6 & CLEAR & $\begin{array}{l}\text { This well turn off } \\
\text { for long time }\end{array}$ & $\begin{array}{l}\text { Pactual } \\
\text { Alarm }\end{array}$ & 0.6828 & 0.0807 & 31.2807 & 0.7290 & Off \\
\hline WB7 & CLEAR & $\begin{array}{l}\text { This well turn off } \\
\text { for long time }\end{array}$ & $\begin{array}{l}\text { Pactual } \\
\text { Alarm }\end{array}$ & 0.6892 & 0.0327 & 31.4327 & 0.7272 & On \\
\hline WB8 & CLEAR & $\begin{array}{l}\text { This well turn off } \\
\text { for long time }\end{array}$ & $\begin{array}{l}\text { Pactual } \\
\text { Alarm }\end{array}$ & 0.9252 & 0.0666 & 32.6666 & 0.7099 & Off \\
\hline WB9 & CLEAR & $\begin{array}{c}\text { This well turn off } \\
\text { for long time }\end{array}$ & $\begin{array}{l}\text { Pactual } \\
\text { Alarm }\end{array}$ & 0.6977 & 0.0285 & 26.2485 & 0.7617 & Off \\
\hline WB10 & CLEAR & $\begin{array}{l}\text { This well turn off } \\
\text { for long time }\end{array}$ & $\begin{array}{l}\text { Pactual } \\
\text { Alarm }\end{array}$ & 0.5871 & 0.2559 & 21.6559 & 0.7417 & On \\
\hline WB11 & CLEAR & $\begin{array}{l}\text { This well turn off } \\
\text { for long time }\end{array}$ & $\begin{array}{l}\text { Pactual } \\
\text { Alarm }\end{array}$ & 0.5338 & 0.2531 & 18.6531 & 0.7027 & On \\
\hline WB12 & CLEAR & $\begin{array}{l}\text { This well turn off } \\
\text { for long time }\end{array}$ & $\begin{array}{l}\text { Pactual } \\
\text { Alarm }\end{array}$ & 0.5928 & 0.1480 & 21.9480 & 0.7444 & On \\
\hline WB13 & CLEAR & $\begin{array}{l}\text { This well turn off } \\
\text { for long time }\end{array}$ & $\begin{array}{l}\text { Pactual } \\
\text { Alarm } \\
\end{array}$ & 0.5958 & 0.0967 & 22.0967 & 0.7457 & On \\
\hline WB14 & CLEAR & This well turn off & Pactual & 0.5693 & 0.1160 & 20.7160 & 0.7317 & On \\
\hline
\end{tabular}




\begin{tabular}{|c|c|c|c|c|c|c|c|c|}
\hline & & for long time & Alarm & & & & & On \\
\hline WB15 & CLEAR & $\begin{array}{c}\text { This well turn off } \\
\text { for long time }\end{array}$ & $\begin{array}{c}\text { Pactual } \\
\text { Alarm }\end{array}$ & 0.6116 & 0.1598 & 22.8598 & 0.7516 & 0.7716 \\
\hline WB16 & CLEAR & $\begin{array}{c}\text { This well turn off } \\
\text { for long time }\end{array}$ & $\begin{array}{c}\text { Pactual } \\
\text { Alarm }\end{array}$ & 0.784 & 0.1798 & 23.8598 & Off \\
\hline
\end{tabular}

\section{IV.CONCLUSION}

A designed wireless sensor network structure has been proposed. This sensors are distributed amongst the well-Fieleds in agricultural site; Karbala city, Iraq. The structure monitored the important parameters of each well individually and then collected the overall data

for processing and decision making. A complete analysis is provided for the sensor nodes in terms of power consumption and other factors. Comparison results of the manually selected optimal well-field operation scenarios for the considered farms, listed in Appendix B, with these of the proposed control system, mentioned in Section 4.3, appeared complete similar. This approves the accuracy of the proposed control system in selection of the optimal operation scenario. Generally, the automation of the traditional system provides it with efficiency in terms of accuracy, consumed time and cost. The proposed system tackles the problems of manual management of ground water well field by introducing automated WSN based system. These problems can include labors, operation cost, consumed time, consumed power, and accuracy. In the proposed system, modern software environments are used including $\mathrm{C \#}$ for designing the GUI frames and SQL server for building the considered database. These software environments provide the system with more flexibility and reality that can support the performance efficiency in computing the required parameters. The proposed system reduces the number of employed labor, the consumed power in addition to provide the farms with enough irrigation water with specific scheduling in accurate begins and ends.

\section{REFERENCES}

[1]. David Tood , Larry W.Mays, GroundWater Hydrology , third Edition.

[2]. Jassas H. and Merkel B., "Estimating Groundwater Recharge in the Semiarid Al-Khazir Gomal Basin, North Iraq", Water Journal, Vol. 6(8), pp. 2467-2481. (2014)

[3]. Srikanth Anumalla , and David C. Gosselin , "Ground Water Monitoring using Smart Sensors" IEEE International Conference on Electro Information Technology, 2005.

[4]. M. Mafuta, M. Zennaro, A. Bagula, G. Ault, H. Gombachika and T. Chadza, "Successful Deployment of a Wireless Sensor Network for Precision Agriculture in Malawi", International Journal of Distributed Sensor Networks, Vol.2013, PP.1-13, 2013

[5]. Jin-Yong Lee, and Kideok D. Kwon, "Current Status of Groundwater Monitoring Networks in Korea "article water http://creativecommons.org/licenses/by/4.0/2016. 66]M. Popa, O. Prostean and A.S. Popa, "A Classification of Solutions for the Energy Limitation in Wireless Sensor Networks", IEEE 9th International Conference on Computational Cybernetics, PP.293-297, 2013.

[6]. P. Tyagi and S. Jain, "Comparative Study of Routing Protocols in Wireless Sensor Network", International Journal of Advanced Research in Computer Science and Software Engineering, Vol.2, No.9, PP.134-140, 2012.

[7]. S. Ahirwar and P. Tanwar, "A Review of Power Optimization Strategies in Wireless Sensor Network", International Journal of Emerging Technology and Advanced Engineering (IJETAE), Vol.3, No.10, PP.212-218, 2013.

[8]. P. Jurmk, "Real-time Communication over Cluster-tree Wireless Sensor Networks", Ph.D. thesis, Czech Technical University in Prague, 2010 .

[9]. K. Kondaiah, R.B. Babu and S. Umar, "A Study on Routing Protocols in Wireless Sensor 
Networks", International Journal of Computer Science Engineering and Technology (IJCSET), Vol.3, No.3, PP.94-98, 2013.

[10]. S. E. Díaz, J. C. Perez, A. C. Mateos, M.-C. Marinescu, and B. B. Guerra, Computers and Electronics in Agriculture 76, 252 (2011).

[11]. S. M. Abd El-kader and B. M. M. El-Basioni, "Precision farming solution in Egypt using the wireless sensor network technology", Egyptian Informatics Journal, Vol.14, No.3, PP.221-233, 2013.

Cite this article as :

Alaa. Qassim Rahima, Hiba. A. Tarish, Narjis. Sapih, 'Monitoring and Control System by Using Wireless Sensor Network for Ground water Well's Field in South of Iraq ', International Journal of Scientific Research in Science and Technology(IJSRST),Print ISSN : 2395-6011, Online ISSN : 2395-602X,Volume 4 Issue 11, pp. 311-318, November-December 2018.

Available at doi :

https://doi.org/10.32628/IJSRST18401155

Journal URL : http://ijsrst.com/IJSRST18401155 